\title{
Haloanaerobium kushneri sp. nov., an obligately halophilic, anaerobic bacterium from an oil brine
}

\author{
Vishvesh K. Bhupathiraju, ${ }^{1} \ddagger$ Michael J. McInerney, ${ }^{1}$ Carl R. Woese ${ }^{2}$ \\ and Ralph S. Tanner ${ }^{1}$
}

Author for correspondence: Michael J. McInerney. Tel: +1 405325 6050. Fax: +1 4053257619. e-mail: mcinerney@ou.edu

1 Department of Botany and
Microbiology, University of
Oklahoma, 770 Van Vleet
Oval, Norman, OK 73019-
0245, USA
2 Department of
Microbiology, University of
Illinois, Urbana, IL 61801,
USA

\begin{abstract}
Three strains, designated VS-751', VS-511 and VS-732, of a strictly anaerobic, moderately halophilic, Gram-negative, rod-shaped bacterium were isolated from a highly saline (15-20\%) brine from an oil reservoir in central Oklahoma, USA. The optimal concentration of $\mathrm{NaCl}$ for growth of these three strains was $2 \mathrm{M}(12 \%)$, and the strains also grew in the presence of an additional $1 \mathrm{M}$ $\mathrm{MgCl}_{2}$. The strains were mesophilic and grew at a pH range of 6-8. Carbohydrates used by all three strains included glucose, fructose, arabinose, galactose, maltose, mannose, cellobiose, sucrose and inulin. Glucose fermentation products included ethanol, acetate, $\mathrm{H}_{2}$ and $\mathrm{CO}_{2}$, with formate produced by two of the three strains. Differences were noted among strains in the optimal temperature and $\mathrm{pH}$ for growth, the maximum and minimum $\mathrm{NaCl}$ concentration that supported growth, substrate utilization and cellular fatty acid composition. Despite the phenotypic differences among the three strains, analysis of the 16S rRNA gene sequences and DNA-DNA hybridizations showed that these three strains were members of the same genospecies which belonged to the genus Haloanaerobium. The phenotypic and genotypic characteristics of strains VS-751', VS-511 and VS-732 are different from those of previously described species of Haloanaerobium. It is proposed that strain VS-751' (ATCC 700103') be established as the type strain of a new species, Haloanaerobium kushneri.
\end{abstract}

Keywords: halophile, anaerobe, Haloanaerobiaceae, Haloanaerobium kushneri

\section{INTRODUCTION}

Hypersaline environments are inhabited by a wide variety of aerobic and anaerobic micro-organisms. Anaerobic bacteria from these environments include phototrophs, acetogens, methanogens, sulfatereducers, and members of the Haloanaerobiaceae and Halobacteroidaceae (Ollivier et al., 1994; Rainey et al., 1995). In the family Haloanaerobiaceae, the genus with the largest number of described species is Haloanaerobium, which includes: Haloanaerobium praevalens (Rainey et al., 1995; Zeikus et al., 1983), Haloanaerobium acetoethylicum (formerly Halobacteroides

¥Present address: Department of Civil and Environmental Engineering, University of California, Berkeley, CA 94720, USA.

The GenBank accession numbers for the (1500 nucleotide) 16S rRNA sequences for strain $\mathrm{VS}-751^{\top}$ and $H$. acetoethylicum ATCC $43120^{\top}$ are U86446 and U86448. acetoethylicus) (Patel et al., 1995; Rengpipat et al., 1988), Haloanaerobium alcaliphilum (Rainey et al., 1995; Tsai et al., 1995), Haloanaerobium lacusroseus (Cayol et al., 1995), Haloanaerobium saccharolyticum subsp. saccharolyticum (formerly Haloincola saccharolyticum subsp. saccharolyticum) (Rainey et al., 1995; Tourova et al., 1995; Zhilina et al., 1992), Haloanaerobium saccharolyticum subsp. senegalensis (formerly Haloincola saccharolyticum subsp. senegalensis) (Cayol et al., 1994; Rainey et al., 1995), Haloanaerobium congolense (Ravot et al., 1997) and Haloanaerobium salsugo (Bhupathiraju et al., 1994a). These are all halophilic, obligately anaerobic, Gramnegative, fermentative bacteria.

H. salsugo (Bhupathiraju et al., 1994a) and a new genus of halophilic aerobic bacteria, Arhodomonas (Adkins et al., 1993), were isolated from highly saline brine produced from a sandstone oil reservoir in Payne 
County, OK, USA, during a pretest study for a microbially-enhanced oil recovery pilot field project (Bhupathiraju et al., 1991, 1993). A diverse array of aerobic heterotrophs, anaerobic heterotrophs, methanogens, sulfate reducers, and bacteria with metabolisms useful for enhanced oil recovery have also been recovered from produced brine from this oil reservoir (Bhupathiraju et al., 1991, 1993). These studies support the conclusion that active and diverse microbial communities are present in hypersaline oil reservoirs.

Several fermentative, anaerobic, halophilic bacteria recovered from this brine were studied further. Three strains, VS-751 ${ }^{\mathrm{T}}$, VS-732 and VS-511, are described in the present report. These are shown to be strains of a single species which is genotypically and phenotypically distinct from the described species in the genus Haloanaerobium. We propose the name Haloanaerobium kushneri for these strains with strain VS-751 ${ }^{\mathrm{T}}$ as the type strain of $H$. kushneri. A portion of this work has appeared previously (Bhupathiraju et al., 1994b).

\section{METHODS}

Strains. Haloanaerobium acetoethylicum [formerly Halobacteroides acetoethylicus (Rainey et al., 1995; Rengpipat et al., 1988)] ATCC $43120^{\mathrm{T}}$ and Haloanaerobium praevalens ATCC $33744^{\mathrm{T}}$ were obtained from American Type Culture Collection, Manassas, VA, USA. Haloanaerobium saccharolyticum [formerly Haloincola saccharolytica (Rainey et al., 1995; Zhilina et al., 1992)] subsp. saccharolyticum (= DSM $6643^{\mathrm{T}}$ ) was kindly provided by Dr T. N. Zhilina. Haloanaerobium salsugo $\left(=\right.$ ATCC $\left.51327^{\mathrm{T}}\right)$ was from our culture collection. Strains VS-751 ${ }^{\mathrm{T}}$, VS-511 and VS-732 were isolated from a hypersaline oil brine in Payne County, Oklahoma, as previously described (Bhupathiraju et al., 1991, 1993, 1994a, b). Haloanaerobium kushneri strain VS$751^{\mathrm{T}}$ was deposited in the American Type Culture Collection as ATCC $700103^{\mathrm{T}}$.

Media and culture methods. The basal medium contained (g $\left.1^{-1}\right): \mathrm{NaCl}, 120 ; \mathrm{NH}_{4} \mathrm{Cl}, 1 \cdot 0 ; \mathrm{KCl}, 0 \cdot 1 ; \mathrm{KH}_{2} \mathrm{PO}_{4}, 0 \cdot 1 ;$ $\mathrm{MgSO}_{4} .7 \mathrm{H}_{2} \mathrm{O}, 0 \cdot 2 ; \mathrm{CaCl}_{2} .2 \mathrm{H}_{2} \mathrm{O}, 0 \cdot 04 ;$ PIPES dipotassium salt, 1.5 ; yeast extract, 0.25 ; resazurin, 0.0005 ; cysteine hydrochloride, 0.5 ; and $\mathrm{Na}_{2} \mathrm{~S} .9 \mathrm{H}_{2} \mathrm{O}, 0.5$, as well as $5 \mathrm{ml}$ trace metal solution (Tanner, 1997), $10 \mathrm{ml}$ vitamin solution (Tanner, 1997) and a $\mathrm{N}_{2}$ gas phase. The $\mathrm{pH}$ was $7 \cdot 1-7 \cdot 3$. A complex medium contained the basal medium described above supplemented with $\left(\mathrm{g} \mathrm{l}^{-1}\right)$ : Casamino acids, $1 \cdot 0$; yeast extract, 1.0 ; and glucose, $5 \cdot 0$. Solid media were prepared by the addition of $20 \mathrm{~g}$ purified agar $\mathrm{l}^{-1}(\mathrm{BBL})$. Methods for the preparation and use of anaerobic media were those of Balch $\&$ Wolfe (1976). Cultures were routinely maintained in the complex medium by transfer once every week.

Metabolic and growth characteristics. All experiments were performed in duplicate or triplicate at $37^{\circ} \mathrm{C}$, unless otherwise indicated. The temperature and $\mathrm{NaCl}$ ranges for growth were determined with complex medium. The effect of magnesium ion on growth was examined with complex medium containing $2 \mathrm{M} \mathrm{NaCl}$. The effect of $\mathrm{pH}$ on growth was tested in complex medium with $100 \mathrm{mM}$ MOPS buffer and a $\mathrm{N}_{2}$ gas phase. The $\mathrm{pH}$ was adjusted with $10 \mathrm{M} \mathrm{NaOH}$ or $\mathrm{HCl}$. The ability of strains VS-751 ${ }^{\mathrm{T}}$, VS-511, VS-732, $H$. acetoethylicum ATCC $43120^{\mathrm{T}}$ and $H$. praevalens ATCC $33744^{\mathrm{T}}$ to utilize different substrates was tested in basal medium with the test compounds at $10 \mathrm{mM}$. Complex substrates were added at a concentration of $5 \mathrm{~g} \mathrm{l}^{-1}$. The use of a compound or combination of compounds was scored as positive when growth occurred in at least three serial transfers. The effect of external electron acceptors on growth was tested in the basal medium with glucose $(10 \mathrm{mM})$ as an electron donor. Compounds tested as electron acceptors included elemental sulfur, sodium sulfate, sodium thiosulfate, sodium sulfite, sodium nitrate, and sodium nitrite at a concentration of $3 \mathrm{~g} \mathrm{l}^{-1}$. Amino acid combinations tested included alanine-glycine, leucine-proline, isoleucine-tryptophan, valine-ornithine, phenylalanine-leucine and histidinesarcosine.

Glucose fermentation products were determined in basal medium containing $10 \mathrm{~g}$ glucose $1^{-1}$ and a $\mathrm{N}_{2}$ gas phase. Volatile fatty acids and alcohols in the liquid phase and $\mathrm{CO}_{2}$ and $\mathrm{H}_{2}$ in the gas phase were analysed at the beginning of the experiment and after $4 \mathrm{~d}$ incubation.

Gram stains were performed using both heat-fixed smears and smears fixed with acetic acid as described previously (Dussault, 1955). Antibiotic susceptibility tests were performed by adding filter-sterilized antibiotics to growth medium at a final concentration of $10 \mu \mathrm{g} \mathrm{ml}^{-1}$. Sodium azide was tested at $50 \mu \mathrm{g} \mathrm{ml}^{-1}$. Tests for catalase activity, oxidase activity, motility and spore formation were performed as described previously (Smibert \& Krieg, 1994).

Analytical techniques. Growth was monitored by measuring the increase in $\mathrm{OD}_{660}$ (Balch \& Wolfe, 1976). Glucose was measured by the glucose oxidase method (Sigma). Volatile fatty acids, alcohols and gases were analysed as described previously (Bhupathiraju et al., 1991, 1994a).

Microscopy. Transmission electron microscopy was performed using a JEOL JEM $2000 \mathrm{FX}$ transmission electron microscope. Micrographs were prepared from exponentialphase cells grown in complex medium. The cells were fixed with $1 \%$ glutaraldehyde in $12 \% \mathrm{NaCl}$, spread onto carboncoated Formvar grids and stained with $1 \%$ phosphotungstate ( $\mathrm{pH} 7 \cdot 0)$.

Cellular fatty acid analysis. The cellular fatty acid composition of cells of strains VS-751 ${ }^{\mathrm{T}}$, VS-511, VS-732, $H$. acetoethylicum ATCC $43120^{\mathrm{T}}$ and $H$. praevalens ATCC $33744^{\mathrm{T}}$ grown in the complex medium containing $10 \% \mathrm{NaCl}$ was determined. Cellular fatty acid analysis was performed by Microcheck. Whole-cell fatty acids were analysed as fatty acid methyl esters with a MIDI microbial identification system. Fatty acid methyl esters were synthesized and analysed as described previously (Miller, 1982; Moss et al., 1998; Sassar, 1990).

DNA base composition. DNAs were isolated and purified as described previously (Marmur, 1961). The $\mathrm{G}+\mathrm{C}$ content was determined by the HPLC method of Mesbah et al. (1989). Non-methylated $\lambda$ phage DNA was used for calibration.

DNA-DNA hybridization. Isolated DNA from strains VS$751^{\mathrm{T}}$, VS-511 and VS-732 and other Haloanaerobium species were nick translated with $\left[{ }^{32} \mathrm{P}\right] \mathrm{dCTP}$ using a nick translation kit (Boehringer Mannheim Biochemica). The labelled DNA was purified with Quick Spin Columns (Boehringer Mannheim Biochemica) and ethanol precipitation. DNADNA reassociation was performed by using the free-solution method and analysed by the $\mathrm{S} 1$ nuclease procedure (Johnson, 1994). Reassociation mixtures contained $12.5 \%$ formamide and reassociation was performed at $T_{\mathrm{m}}-25^{\circ} \mathrm{C}$ of the radiolabelled DNA. The $T_{\mathrm{m}}$ was calculated from the $\mathrm{mol} \% \mathrm{G}+\mathrm{C}$ content using the equation $T_{\mathrm{m}}=$ 
$64.9{ }^{\circ} \mathrm{C}+(0 \cdot 5025 \times[\mathrm{mol} \% \mathrm{G}+\mathrm{C}])$ and was further reduced by $0.62{ }^{\circ} \mathrm{C}$ for each percentage formamide in solution.

16S rRNA sequence analysis. The $16 \mathrm{~S}$ rRNAs were sequenced by methods described previously (Lane et al., 1985; Oyaizu et al., 1987). Sequences were analysed by distance matrix analysis with a program for fitting trees to distance data (De Soete, 1983; Jukes \& Cantor, 1969; Oyaizu et al., 1987). A minimum of 1500 nucleotide positions were used in tree construction.

\section{RESULTS AND DISCUSSION}

\section{Genetic analysis}

Strains VS-751 ${ }^{\mathrm{T}}$, VS-511 and VS-732 had the same 16S rRNA gene sequence. Distance matrix analysis showed that these three strains were closely related to members of the genus Haloanaerobium (Fig. 1). The 16S rRNA gene sequence of strain VS-751 $1^{\mathrm{T}}$ was $1.9 \%$ different from that of Haloanaerobium acetoethylicum and $2 \cdot 1 \%$ different from that of Haloanaerobium praevalens.

The discovery that strains VS-751 ${ }^{\mathrm{T}}$, VS-511 and VS732 had identical 16S rRNA gene sequences was not expected given the phenotypic differences among the three strains in motility, substrate utilization, cellular fatty acid composition, and other phenotypic proper-

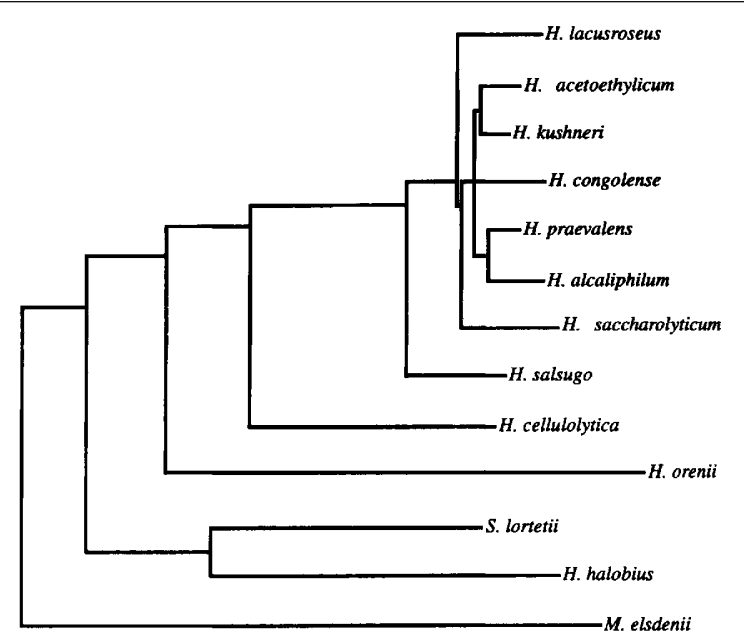

0.10

Fig. 1. Phylogenetic relationships of $H$. kushneri $\mathrm{VS}-751^{\top}$ to other bacteria. The total horizontal distance between two species indicates the level of difference in their sequences. Bar indicates an evolutionary distance of 0.1. Type species used for this analysis (with gene accession numbers in parentheses) are as follows: Haloanaerobium lacusroseus strain DSM $10165^{\top}$ (L39767) (Cayol et al., 1995); Haloanaerobium salsugo ATCC $43120^{\top}$ (L22890), Haloanaerobium praevalens ATCC $33744^{\top}$ (M59123) and Sporohalobacter lortetii ATCC $35059^{\top}$ (M59122) (Bhupathiraju et al., 1994a); Haloanaerobium congolense DMS $11287^{\top}$ (Ravot et al., 1997); Haloanaerobium alcaliphilum DMS $8275^{\top}$ (X81850) (Tsai et al., 1995); Halothermothrix orenii OMC 544 (L22016) (Cayol et al., 1994); Haloanaerobium saccharolyticum DSM 6643' (X89069); Halocella cellulolytica DSM $7362^{\top}$ (X89072); Halobacteroides halobius DSM $5150^{\top}$ (X89074) (Rainey et al., 1995); and Megasphaera elsdenii (M26493) (Zhao et al., 1989). ties (below; Bhupathiraju et al., 1991). However, the results of DNA-DNA hybridization showed that strains VS-751 ${ }^{\mathrm{T}}$, VS-511 and VS-732 were members of a single genospecies, with percentage DNA-DNA hybridization values of $89 \%$ or higher (Table 1). Also, these three strains were not related at the species level to the two Haloanaerobium species with the most similar $16 \mathrm{~S}$ rRNA gene sequences, $H$. acetoethylicum and $H$. praevalens.

The mol $\% \mathrm{G}+\mathrm{C}$ content of the DNA from strains VS-751 ${ }^{\mathrm{T}}$, VS-511 and VS-732 was ( \pm standard deviations of four replicates) $34 \cdot 1 \pm 0 \cdot 2,36 \cdot 9 \pm 0 \cdot 1$ and $32 \cdot 4 \pm 0 \cdot 2$, respectively.

\section{Cellular characteristics}

Strains VS-751 ${ }^{\mathrm{T}}$, VS-511 and VS-732 were all nonspore-forming, Gram-negative, rod-shaped bacteria. Colonies on complex medium are circular, entire, opaque, white in colour and $2 \mathrm{~mm}$ in diameter. Cells of strains VS-751 $1^{\mathrm{T}}$ and VS-732 were actively motile and measured $0.7 \times 2.0-3.3 \mu \mathrm{m}$ and $0.5 \times 0.7-1.9 \mu \mathrm{m}$, respectively. Strain VS-511 was not motile and the size of the cells was $0.8 \times 1.3-2.6 \mu \mathrm{m}$. Cells of all three strains appeared singly or in pairs. Strain VS-751 $1^{\mathrm{T}}$ had peritrichously arranged flagella (Fig. 2).

The variability in cell size among strains VS-751 ${ }^{\mathrm{T}}$, VS511 and VS-732, while seemingly unusual, is similar to the variability in cell size observed in other halophilic eubacteria, which are sometimes described as pleomorphic, especially in older cultures. For example, the cell size of the two subspecies of Haloanaerobium saccharolytica varied from $0.5-0.7 \times 1.0-1.5 \mu \mathrm{m}$ for one subspecies to $0.4-0.6 \times 2.0-5.0 \mu \mathrm{m}$ for the other subspecies (Cayol et al., 1994; Zhilina et al., 1992).

\section{Growth and metabolic characteristics}

Strains VS-751 ${ }^{\mathrm{T}}$, VS-511 and VS-732 required anaerobic conditions for growth. The strains were obligately halophilic, with an optimal $\mathrm{NaCl}$ requirement of $12 \%$ ( $2 \mathrm{M}$ ) (Fig. 3). The strains also grew in medium containing $1 \mathrm{M} \mathrm{MgCl} \cdot 6 \mathrm{H}_{2} \mathrm{O}$ in addition to $2 \mathrm{M} \mathrm{NaCl}$. Strains VS-751 ${ }^{\mathrm{T}}$ (Fig. 3) and VS-511 grew at $\mathrm{NaCl}$ concentrations between 9 and $18 \%$, and strain VS-732 grew at $\mathrm{NaCl}$ concentrations between 6 and $25 \%$. The growth rates under optimal $\mathrm{NaCl}$ conditions at $37^{\circ} \mathrm{C}$ and an initial $\mathrm{pH}$ of 7.2 for strains $\mathrm{VS}-751^{\mathrm{T}}$, VS-511 and VS-732 were 0.095, 0.086 and 0.063 $\mathrm{h}^{-1}$, respectively.

The temperature ranges (with the optimum temperature given in parentheses) for strains VS-751 ${ }^{\mathrm{T}}$, VS-511 and VS-732 were $20-45^{\circ} \mathrm{C}\left(40^{\circ} \mathrm{C}\right), 20-37^{\circ} \mathrm{C}\left(35^{\circ} \mathrm{C}\right)$ and $20-37^{\circ} \mathrm{C}\left(35^{\circ} \mathrm{C}\right)$, respectively. The $\mathrm{pH}$ range for growth of all three strains was $6 \cdot 0-8 \cdot 0$. The $\mathrm{pH}$ optima for strains VS-751 ${ }^{\mathrm{T}}$, VS-511 and VS-732 were $6 \cdot 5-7 \cdot 5$, $7 \cdot 0$ and $6 \cdot 5$, respectively.

The substrates that supported the growth of the these strains were predominantly carbohydrates, in common with other species of Haloanaerobium (Rainey et al., 
Table 1. Levels of DNA relatedness between strains VS- $751^{\top}$ and VS-732 and other species in the genus Haloanaerobium

Data are means \pm standard deviation of three replicates. A value of $100 \%$ indicates homologous hybridization.

\begin{tabular}{|c|c|c|}
\hline \multirow[t]{2}{*}{ Source of unlabelled DNA } & \multicolumn{2}{|c|}{$\begin{array}{l}\text { DNA hybridization (\%) with } \\
\text { 32P-labelled DNA from: }\end{array}$} \\
\hline & VS-751 ${ }^{\mathrm{T}}$ & VS-732 \\
\hline Strain VS-751 ${ }^{\mathrm{T}}$ & 100 & $91 \pm 1$ \\
\hline Strain VS-732 & $98 \pm 1$ & 100 \\
\hline Strain VS-511 & $98 \pm 1$ & $89 \pm 1$ \\
\hline H. acetoethylicum ATCC $43120^{\mathrm{T}}$ & $37 \pm 3$ & $40 \pm 1$ \\
\hline H. saccharolyticum subsp. saccharolyticum DSM $6643^{\mathrm{T}}$ & $28 \pm 1$ & $25 \pm 2$ \\
\hline H. salsugo ATCC $51327^{\mathrm{T}}$ & $25 \pm 3$ & $22 \pm 2$ \\
\hline H. praevalens ATCC $33744^{\mathrm{T}}$ & $18 \pm 2$ & $16 \pm 1$ \\
\hline
\end{tabular}

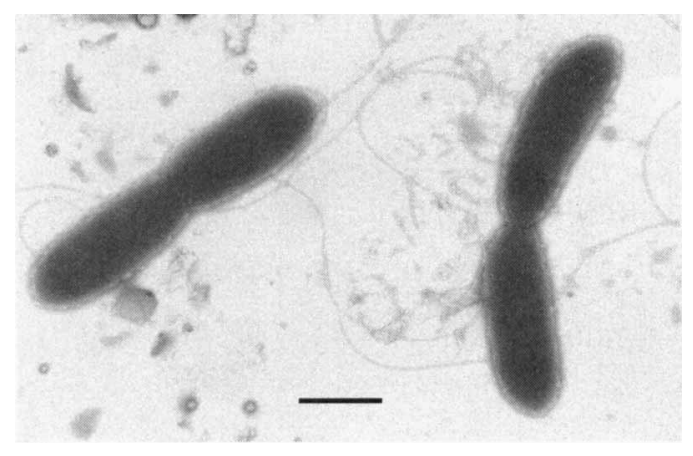

Fig. 2. Transmission electron micrograph of a negatively stained cell of $H$. kushneri VS-751 ${ }^{\top}$. Bar, $1 \mu \mathrm{m}$.

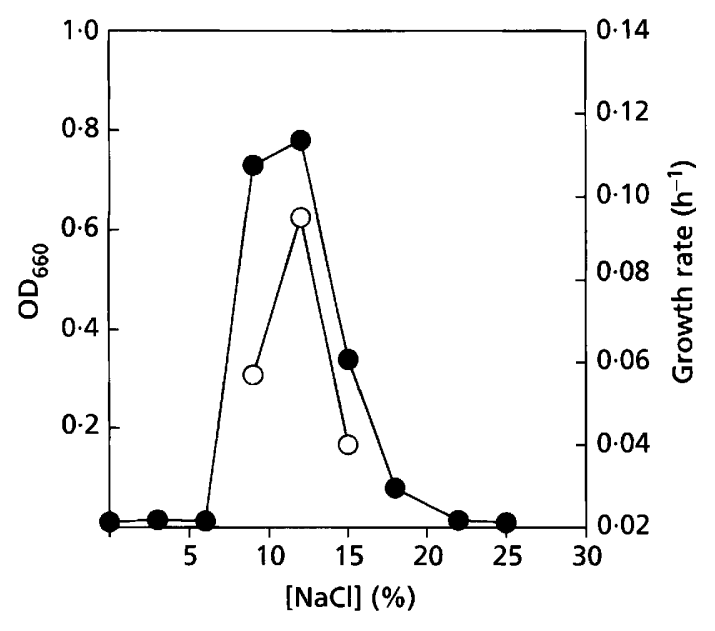

Fig. 3. Effect of $\mathrm{NaCl}$ concentration on maximum absorbance (O) and growth rate (O) of strain VS- $751^{\top}$.

1995). Strain VS- $751^{\mathrm{T}}$ used arabinose, cellobiose, fructose, galactose, glucose, inulin, lactose, maltose, mannose, peptone, pyruvate, sucrose and trypticase.
There was variability observed among the strains in types of substrates used. In addition to using the substrates used by strain VS-751 ${ }^{\mathrm{T}}$, strain VS-511 also used fucose, glucosamine, glycerol, mannitol, sorbose and xylose. The substrate utilization profile of strain VS-732 was similar to that of strain VS-751 ${ }^{\mathrm{T}}$, except strain VS-732 also used fucose and xylose, but not lactose and pyruvate. Substrates that did not support growth of any of the three strains included L-alanine, L-ascorbate, adonitol, betaine, butyrate, cellulose, chitin, crotonate, dulcitol, formate, fumarate, glutamate, glycine, glycogen, inositol, lactate, L-lysine, malate, methanol, methionine, pectin, proline, propionate, starch, succinate, sarcosine and sorbitol. The amino acid mixtures of alanine-glycine, leucine-proline, isoleucine-tryptophan, valine-ornithine, phenylalanine-leucine and histidine-sarcosine did not support growth of any of the strains.

Strain VS-751 $1^{\mathrm{T}}$ differed from $H$, praevalens ATCC $43120^{\mathrm{T}}$ in its ability to use arabinose, cellobiose, galactose, lactose, pyruvate and sucrose, and in its inability to use glucosamine. Strain VS-751 ${ }^{\mathrm{T}}$ differed from $H$. acetoethylicum ATCC $33744^{\mathrm{T}}$ in its ability to use galactose and its inability to use glucosamine and xylose.

The major fermentation products from glucose were ethanol, acetate, $\mathrm{CO}_{2}$ and $\mathrm{H}_{2}$ (Table 2). Strains VS$751^{\mathrm{T}}$ and VS-732 also produced formate. Growth of all three strains was inhibited by chloramphenicol, tetracycline or penicillin, but not by cycloheximide or azide. Nitrate, nitrite, sulfate, sulfite, thiosulfate and elemental sulfur did not stimulate growth of any of the strains. All three strains were oxidase and catalasenegative.

The differences among strains VS-751 ${ }^{\mathrm{T}}$, VS-511 and VS-732 in certain growth and metabolic characteristics is not inconsistent with these strains being members of the same species. There are clear differences in substrate utilization, $\mathrm{NaCl}$ concentration tolerance and doubling times under the same growth conditions 
Table 2. Glucose fermentation products

Each value reported is mol product formed per mol glucose fermented. Carbon recoveries were 103, 98 and $91 \%$ for strains VS-751 ${ }^{\mathrm{T}}$, VS-511 and VS-732, respectively. Hydrogen recoveries were 101,102 and $88 \%$ for strains VS-751 ${ }^{\mathrm{T}}$, VS511 and VS-732, respectively.

\begin{tabular}{|llll|}
\hline Product & VS-751 $^{\text {T }}$ & VS-511 & VS-732 \\
\hline Ethanol & 1.4 & 1.4 & 1.0 \\
Acetate & 0.58 & 0.67 & 0.70 \\
Formate & 0.32 & ND & 0.32 \\
$\mathrm{CO}_{2}$ & 1.9 & 1.7 & 1.7 \\
$\mathrm{H}_{2}$ & 0.52 & 0.53 & 0.48 \\
\hline
\end{tabular}

ND, Not detected.

Table 3. Cellular fatty acid compositions of halophilic anaerobes

Strains: 1 , VS-751 ${ }^{\mathrm{T}} ; 2$, VS-51 $1 ; 3$, VS-732; $4, H$. praevalens ATCC $33744^{\mathrm{T}} \uparrow ; 5, H$. acetoethylicum ATCC $43120^{\mathrm{T}} \dagger$

\begin{tabular}{|c|c|c|c|c|c|}
\hline \multirow[t]{2}{*}{ Fatty acid* } & \multicolumn{5}{|c|}{$\begin{array}{c}\text { Cellular fatty acid composition } \\
(\%) \text { of strain: }\end{array}$} \\
\hline & 1 & 2 & 3 & $4 \dagger$ & $5 \dagger$ \\
\hline $\mathrm{C}_{10: 0} 3-\mathrm{OH}$ & $2 \cdot 7$ & $2 \cdot 4$ & $2 \cdot 2$ & $0 \cdot 9$ & $3 \cdot 2$ \\
\hline $\mathrm{C}_{12: 0} 3-\mathrm{OH}$ or $\mathrm{C}_{13: 0}$ & $4 \cdot 1$ & $3 \cdot 3$ & $2 \cdot 7$ & $2 \cdot 7$ & $3 \cdot 5$ \\
\hline $\mathrm{C}_{14: 0}$ & $9 \cdot 3$ & 6.6 & $9 \cdot 1$ & $8 \cdot 4$ & $11 \cdot 2$ \\
\hline $\mathrm{C}_{16: 0}^{14.0}$ & $34 \cdot 9$ & 35 & $22 \cdot 1$ & $25 \cdot 8$ & $20 \cdot 4$ \\
\hline $\mathrm{C}_{16: 1} \operatorname{cis} 7$ & $8 \cdot 1$ & $7 \cdot 4$ & $12 \cdot 0$ & $11 \cdot 4$ & $12 \cdot 0$ \\
\hline $\mathrm{C}_{16: 1}$ cis 9 & $22 \cdot 5$ & $21 \cdot 6$ & $38 \cdot 5$ & $36 \cdot 8$ & $37 \cdot 6$ \\
\hline $\mathrm{C}_{16: 1} \operatorname{cis} 11$ & $4 \cdot 0$ & $4 \cdot 3$ & $6 \cdot 7$ & 6.8 & $5 \cdot 3$ \\
\hline $\mathrm{C}_{17: 0} \mathrm{cyc}$ & $7 \cdot 8$ & $9 \cdot 4$ & $1 \cdot 0$ & & $1 \cdot 1$ \\
\hline
\end{tabular}

*3-OH, 3-hydroxy; cyc, cyclic.

$\uparrow$ Cultures grown in the same medium at the same time as strains VS-751 ${ }^{\mathrm{T}}$, VS-511 and VS-732, and data published in Bhupathiruju et al. (1994a).

between the subspecies of $H$. saccharolyticum (Cayol et al., 1994).

\section{Cellular fatty acid composition}

The cellular fatty acid compositions of strains VS$751^{\mathrm{T}}$, VS-511, VS-732, $H$. acetoethylicum ATCC $43120^{\mathrm{T}}$ and $H$. praevalens ATCC $33744^{\mathrm{T}}$, cultured under the same conditions and harvested while in exponential growth, are given in Table 3. Fatty acids, hydroxy fatty acids and aldehydes [from plasmalogens (Jantzen \& Hofstad, 1981)] were found, with variants of $\mathrm{C}_{16}$ compounds prevalent, as was observed in the cellular fatty acid compositions of $H$. praevalens ATCC $33744^{\mathrm{T}}$ and $H$. acetoethylicum ATCC $43120^{\mathrm{T}}$ (Table 3) and $H$. salsugo (Bhupathiraju et al., 1994a).
Again, while variations in the cellular fatty acid compositions of strains VS-751 ${ }^{\mathrm{T}}$, VS-511 and VS-732 are clearly evident, a similar variability in fatty acid composition was found for strains of $H$. saccharolyticum (Cayol et al., 1994). While these results are not inconsistent with these three strains being members of the same species, they do suggest that cellular fatty acid composition should not be used to determine relatedness of strains of these or other species of Haloanaerobium.

\section{Characteristics that differentiate strains VS-751 ${ }^{\top}$, VS- 511 and VS-732 from the described fermentative halophilic anaerobic bacteria}

Strains VS-751 ${ }^{\mathrm{T}}$, VS-511 and VS-732 were assigned as members of the genus Haloanaerobium by both $16 \mathrm{~S}$ rRNA gene sequence analysis and phenotypic characterization (Rainey et al., 1995). Some of the differences between the VS-751 ${ }^{\mathrm{T}}$, VS-511 and VS-732 strains and the other species of Haloanaerobium are summarized in Table 4. The products of glucose metabolism of strains VS-751 ${ }^{\mathrm{T}}$, VS-511 and VS-732 differ from those of $H$. alcaliphilum, $H$. praevalens, $H$. saccharolyticum and $H$. congolense. In addition, the maximum $\mathrm{pH}$ for growth for strains VS-751 ${ }^{\mathrm{T}}$, VS-511 and VS-732 is $8 \cdot 0$ while $H$. alcaliphilum, $H$. praevalens and $H$. congolense can grow at $\mathrm{pH}$ values greater than 8.0 (Ravot et al., 1997; Zeikus et al., 1983; Tsai et al., 1995). The growth of $H$. lacusroseus was inhibited by magnesium chloride (Cayol et al., 1995) while the three strains examined here tolerated at least $1 \mathrm{M}$ magnesium chloride. $H$. congolense uses thiosulfate and elemental sulfur as electron acceptors (Ravot et al., 1997) while strains VS-751 ${ }^{\mathrm{T}}$, VS-511 and VS-732 do not use these compounds.

The species with the most similar 16S rRNA sequence to strains VS-751 ${ }^{\mathrm{T}}$, VS-511 and VS-732 was $H$. acetoethylicum. The growth of $H$. acetoethylicum was inhibited by magnesium ion concentrations higher than $0 \cdot 2 \mathrm{M}$ (Rengpipat et al., 1988) while strains VS$751^{\mathrm{T}}$, VS-511 and VS-732 grew in the presence of $1 \mathrm{M}$ magnesium ions. $H$. acetoethylicum produced more acetate than ethanol from glucose fermentations (Rengpipat et al., 1988) while strains VS-751 ${ }^{\mathrm{T}}$, VS-511 and VS-732 produced more ethanol than acetate from glucose. The results of the DNA-DNA hybridization analysis showed that the VS strains differed at the species level from $H$. acetoethylicum (Table 1). $H$. praevalens, which had a 16S rRNA gene sequence of $2 \cdot 1 \%$ different from that of strains VS-751 ${ }^{\mathrm{T}}$, VS-511 and VS-732, was also differentiated from these strains by DNA-DNA hybridization analysis.

H. salsugo (Bhupathiraju et al., 1994a) was phenotypically the most similar to strains VS-751 ${ }^{\mathrm{T}}$, VS-511 and VS-732. H. salsugo produced more acetate than ethanol from glucose (Bhupathiraju et al., 1994a), while the opposite was observed for strains VS-751 ${ }^{\mathrm{T}}$, VS-511 and VS-732. The salt optimum for $H$. salsugo was $9 \% \mathrm{NaCl}$ (Bhupathiraju et al., 1994a) compared 
Table 4. Differential characteristics of species of the genus Haloanaerobium

Species: $1, H$. kushneri VS-751 ${ }^{\mathrm{T}} ; 2, H$. acetoethylicum ATCC $43120^{\mathrm{T}} ; 3, H$. alcaliphilum DSM 8275 $; 4$, H. congolense DSM $11287^{\mathrm{T}} ; 5$, H. lacusroseus DSM $10165^{\mathrm{T}} ; 6, H$. praevalens ATCC $33744^{\mathrm{T}} ; 7$, H. saccharolyticum subsp. saccharolyticum DSM $6643^{\mathrm{T}} ; 8, \mathrm{H}$. saccharolyticum subsp. senegalensis DSM 7379 $; 9$, H. salsugo ATCC $51327^{\mathrm{T}}$. Data from this study and Bhupathiraju et al. (1994a), Cayol et al. (1994, 1995), Ravot et al. (1997), Rainey et al. (1995), Rengpipat et al. (1988), Tourova et al. (1995), Tsai et al. (1995), Zeikus et al. (1983) and Zhilina et al. (1992). +, Supported growth; -, did not support growth; ND, not determined; NR, not reported; NA, not applicable.

\begin{tabular}{|c|c|c|c|c|c|c|c|c|c|}
\hline Character & 1 & 2 & 3 & 4 & 5 & 6 & 7 & 8 & 9 \\
\hline Motility & Yes & Yes & Yes & No & Yes & No & Yes & Yes & No \\
\hline \multicolumn{10}{|l|}{ Use of substrates } \\
\hline L-Arabinose & + & + & - & - & - & - & + & - & + \\
\hline Cellobiose & + & + & - & $\mathrm{ND}$ & + & - & + & + & - \\
\hline Galactose & + & - & - & + & + & - & $\mathrm{ND}$ & - & + \\
\hline Gylcerol & - & - & - & ND & + & - & ND & + & - \\
\hline Pectin & - & - & - & $\mathrm{ND}$ & ND & + & - & - & - \\
\hline L-Sorbose & - & - & $\mathrm{ND}$ & $\mathrm{ND}$ & - & - & - & - & + \\
\hline Starch & - & - & - & $\mathrm{ND}$ & + & - & - & $\mathrm{ND}$ & - \\
\hline Sucrose & + & + & + & + & + & - & + & + & + \\
\hline $\begin{array}{l}\text { Products of glucose } \\
\text { fermentation }\end{array}$ & $\begin{array}{l}\text { Ethanol, } \\
\text { acetate, } \\
\text { (formate) } \\
\mathrm{H}_{2}, \mathrm{CO}_{2}\end{array}$ & $\begin{array}{l}\text { Acetate, } \\
\text { ethanol, } \mathrm{H}_{2} \text {, } \\
\mathrm{CO}_{2}\end{array}$ & $\begin{array}{l}\text { Acetate, lactate, } \\
\text { butyrate, } \mathrm{H}_{2} \text {, } \\
\mathrm{CO}_{2}\end{array}$ & $\begin{array}{l}\text { Acetate, } \mathrm{H}_{2}, \\
\mathrm{CO}_{2}\end{array}$ & $\begin{array}{l}\text { Ethanol, } \\
\text { acetate, } \mathrm{H}_{2}, \\
\mathrm{CO}_{2}\end{array}$ & $\begin{array}{l}\text { Acetate, } \\
\text { butyrate, } \mathrm{H}_{2}, \\
\mathrm{CO}_{2}\end{array}$ & $\begin{array}{l}\text { Acetate, } \mathrm{H}_{2} \\
\mathrm{CO}_{2}\end{array}$ & $\begin{array}{l}\text { Acetate, } \mathrm{H}_{2} \\
\mathrm{CO}_{2}\end{array}$ & $\begin{array}{l}\text { Acetate, } \\
\text { ethanol, } \mathrm{H}_{2}, \\
\mathrm{CO}_{2}\end{array}$ \\
\hline Ethanol/acetate ratio & 2.4 & 0.87 & $\mathrm{NA}$ & $\mathrm{NA}$ & $\mathrm{NR}$ & $\mathrm{NA}$ & $\mathrm{NA}$ & $\mathrm{NA}$ & 0.71 \\
\hline
\end{tabular}

* Formate was produced from glucose by two of the three strains of $H$. kushneri, including the type strain.

to $12 \%$ for these three strains. The DNA-DNA hybridization analysis (Table 1) showed that the three VS strains are differentiated at the species level from H. salsugo.

Based on the results presented above, we propose that strains VS-751 ${ }^{\mathrm{T}}$, VS-511 and VS-732 be established as a new species, $H$. kushneri, in the genus Haloanaerobium, with strain VS- $751^{\mathrm{T}}$ designated the type strain of this species.

The phenotypic variability among strains VS-751 ${ }^{\mathrm{T}}$, VS-511 and VS-732 seems unusual since all three strains were isolated from the same hypersaline oil reservoir, which also contained another phenotypically similar species of Haloanaerobium (Bhupathiraju et al., 1991, 1993, 1994a, b). It is easier to understand such variability when strains of the same species are isolated from geographically distinct environments, as with the subspecies of $H$. saccharolyticum (Cayol et al., 1994; Zhilina et al., 1992). It may be that the phenotypic variation observed for the three strains of $H$. kushneri reflects local heterogeneities in the reservoir. Spatially separated habitats are likely to form due to the diffusion-limited movement of cells and nutrients in the reservoir. Such habitats may select for strains with different phenotypic variation properties.

\section{Description of Haloanaerobium kushneri sp. nov.}

Haloanaerobium kushneri (kush'ner.i. M.L. gen. n. kushneri named after Donn J. Kushner, in recognition of his contributions to the microbiology of halophilic bacteria).

Straight, rod-shaped bacterium with cell dimensions of $0.5-0.8 \times 0.7-3.3 \mu \mathrm{m}$. Growing cells appear singly and in pairs and can be motile. The cells stain Gram- negative and are non-spore-forming. Colonies on complex medium are circular, entire, opaque, white in colour and $2 \mathrm{~mm}$ in diameter. Growth in liquid medium is uniform. Growth is inhibited by chloramphenicol, tetracycline and penicillin, but not by cycloheximide or sodium azide. Obligately halophilic. The optimal $\mathrm{NaCl}$ concentration for growth is $12 \%$; growth occurs at $\mathrm{NaCl}$ concentrations of between 9 and $18 \%$. Magnesium chloride concentrations up to $1 \mathrm{M}$ do not inhibit growth. The temperature range is $20-45^{\circ} \mathrm{C}$, with optimum between $35-40^{\circ} \mathrm{C}$. The $\mathrm{pH}$ range is $6 \cdot 0-8.0$, with the optimum between 6.5 and $7 \cdot 5$. Strictly anaerobic and catalase- and oxidase-negative. Fermentative metabolism. The end products of glucose fermentation are ethanol, acetate, $\mathrm{CO}_{2}$ and $\mathrm{H}_{2}$ and, sometimes, formate. The following compounds support growth in a basal medium: L-arabinose, cellobiose, fructose, galactose, D-glucose, inulin, maltose, D-mannose, peptone, sucrose and trypticase. The utilization of fucose, glucosamine, glycerol, lactose, mannitol, pyruvate, sorbose, and xylose is variable among the strains of $H$. kushneri. The following compounds do not support growth in a basal medium: L-alanine, L-ascorbate, adonitol, betaine, butyrate, cellulose, chitin, crotonate, dulcitol, formate, fumarate, glutamate, glycine, glycogen, inositol, lactate, L-lysine, malate, methanol, methionine, pectin, proline, propionate, starch, succinate, sarcosine and sorbitol. Amino acid mixtures such as alanine-glycine, leucine-proline, isoleucine-tryptophan, valineornithine, phenylalanine-leucine and histidine-sarcosine are not utilized. The specific content of major cellular fatty acids is strain-dependent and primarily $\mathrm{C}_{16: 0}$, cis-9 $\mathrm{C}_{16: 1}$, cis-7 $\mathrm{C}_{16: 1}$ and $\mathrm{C}_{14: 0}$ fatty acids. The $\mathrm{G}+\mathrm{C}$ content of the DNA is $32-37 \mathrm{~mol} \%$ and is straindependent (as determined by HPLC). The habitat is 
hypersaline petroleum reservoir production fluid from Payne County, OK, USA. The type strain is VS- $751^{\mathrm{T}}$ $\left(=\operatorname{ATCC} 700103^{\mathrm{T}}\right)$.

\section{ACKNOWLEDGEMENTS}

We thank Pramod Sharma, Kim Fowler, Woody Jenkins, Bryan Hopkins, Richard Raiders, Tue Tue Liu and Neil Wofford for technical assistance, Linda Mandelco for 16S rRNA sequencing, and Greg Strout at the Samuel Roberts Noble Electron Microscopy Laboratory for assistance with the electron microscopy. This work was supported by contracts DE-FG03-96ER20214 from the Department of Energy. Part of this work was supported by grant BSR 8705352 from the National Science Foundation (C.R.W) and grant CA52955 from the National Institutes of Health (R.S.T).

\section{REFERENCES}

Adkins, J. P., Madigan, M. T., Mandelco, L., Woese, C. R. \& Tanner, R. S. (1993). Arhodomonas aquaeolei gen. nov., sp. nov., an aerobic, halophilic bacterium isolated from a subterranean brine. Int J Syst Bacteriol 43, 514-520.

Balch, W. E. \& Wolfe, R. S. (1976). New approach to the cultivation of methanogenic bacteria: 2-mercaptoethanesulfonic acid (HS-CoM)-dependent growth of Methanobacterium ruminantium in a pressurized atmosphere. Appl Environ Microbiol 32, 781-791.

Bhupathiraju, V. K., Sharma, P. K., Mclnerney, M. J., Knapp, R. M., Fowler, K. \& Jenkins, W. (1991). Isolation and characterization of novel halophilic anaerobic bacteria from oil field brines. Dev Petrol Sci 31, 131-143.

Bhupathiraju, V. K., Melnerney, M. J. \& Knapp, R. M. (1993). Pretest studies for a microbial enhanced oil recovery field pilot in a hypersaline oil reservoir. Geomicrobiol J 11, 19-34.

Bhupathiraju, V. K., Oren, A., Sharma, P. K., Tanner, R. S., Woese, C. R. \& Mclnerney, M. J. (1994a). Haloanaerobium salsugo sp. nov., a moderately halophilic, anaerobic bacterium from a subterranean brine. Int $J$ Syst Bacteriol 44, 565-572.

Bhupathiraju, V. K., Tanner, R. S. \& Mclnerney, M. J. (1994b). Characterization of fermentative halophilic anaerobes isolated from subterranean brines. In Abstracts of the 94th General Meeting of the American Society for Microbiology, abstract I-6, p. 254. Washington, DC: American Society for Microbiology.

Cayol, J.-L., Ollivier, B., Lawson, A. S. A., Fardeau, M.-L., Ageron, E., Grimont, P. A. D., Prensier, G., Guezennec, J., Magot, M. \& Garcia, J.-L. (1994). Haloincola saccharolytica subsp. senegalensis subsp. nov., isolated from the sediments of a hypersaline lake, and emended description of Haloincola saccharolytica. Int $J$ Syst Bacteriol 44, 805-811.

Cayol, J.-L., Ollivier, B., Patel, B. K. C., Ageron, E., Grimont, P. A. D., Prensier, G. \& Garcia, J.-L. (1995). Haloanaerobium lacusroseus sp. nov., an extremely halophilic fermentative bacterium from the sediments of a hypersaline lake. Int $J$ Syst Bacteriol 45, 790-797.

De Soete, G. (1983). A least square algorithm for fitting additive trees to proximity data. Psychometrika 48, 621-626.

Dussault, H. P. (1955). An improved technique for staining red halophilic bacteria. $J$ Bacteriol 70, 484-485.

Jantzen, E. \& Hofstad, T. (1981). Fatty acids of Fusobacterium species: taxonomic implications. J Gen Microbiol 123, 163-171. Johnson, J. L. (1994). Similarity analysis of DNA. In Methods for
General and Molecular Bacteriology, pp. 655-682. Edited by P. Gerhardt, R. G. E. Murray, W. A. Wood \& N. R. Krieg. Washington, DC: American Society for Microbiology.

Jukes, T. H. \& Cantor, C. R. (1969). Evolution of protein molecules. In Mammalian Protein Metabolism, vol. 3, pp. 21-132. Edited by H. N. Munro. New York: Academic Press.

Lane, D. J., Pace, B., Olsen, G. J., Stahl, D. A., Sogin, M. L. \& Pace, N. R. (1985). Rapid determination of $16 \mathrm{~S}$ ribosomal RNA sequences for phylogenetic analysis. Proc Natl Acad Sci USA 82, 6955-6959.

Marmur, J. (1961). A procedure for the isolation of deoxyribonucleic acid from micro-organisms. $J \mathrm{Mol} \mathrm{Biol} \mathrm{3,} \mathrm{208-218.}$

Mesbah, M., Premachandran, U. \& Whitman, W. B. (1989). Precise measurement of the $\mathrm{G}+\mathrm{C}$ content of deoxyribonucleic acid by high-performance liquid chromatography. Int $J$ Syst Bacteriol 39, 159-167.

Miller, L. T. (1982). Single derivatization method for routine analysis of bacterial whole-cell fatty acid methyl esters, including hydroxy acids. J Clin Microbiol 16, 584-586.

Moss, C. W., Wallace, P. L., Hollis, D. G. \& Weaver, R. E. (1988). Cultural and chemical characterization of CDC groups EO-2, M-5, and M-6, Moraxella, (Moraxella) species, Oligella urethralis, Acinetobacter species, and Psychrobacter immobilis. $J$ Clin Microbiol 26, 484-492.

Ollivier, B., Caumette, P., Garcia, J.-L. \& Mah, R. A. (1994). Anaerobic bacteria from hypersaline environments. Microbiol Rev 58, 27-38.

Oyaizu, H., Debrunner-Vossbrinck, B., Mandelco, L., Studier, J. A. \& Woese, C. R. (1987). The green non-sulfur bacteria: a deep branching in the eubacterial line of descent. Syst Appl Microbiol 9, 47-53.

Patel, B. K. C., Andrew, K. T., Ollivier, B., Mah, R. A. \& Garcia, J. L. (1995). Re-evaluating the classification of Halobacteroides and Haloanaerobacter species based on sequence comparisons of the 16S ribosomal RNA gene. FEMS Microbiol Lett 134, 115-119.

Rainey, F. A., Zhilina, T. N., Boulygina, E. S., Stackebrandt, E., Tourova, T. P. \& Zavarzin, G. A. (1995). The taxonomic status of the fermentative halophilic anaerobic bacteria: description of Haloanaerobiales ord. nov., Halobacteroidaceae fam. nov., Orenia gen. nov. and further taxonomic rearrangements at the genus and species level. Anaerobe 1, 185-199.

Ravot, G., Magot, M., Ollivier, B., Patel, B. K. C., Ageron, E., Grimont, P. A. D., Thomas, P. \& Garcia, J.-L. (1997). Haloanaerobium congolense sp. nov., an anaerobic, moderately halophilic, thiosulfate- and sulfur-reducing bacterium from an African oil field. FEMS Microbiol Lett 147, 81-88.

Rengpipat, S., Langworthy, T. A. \& Zeikus, J. G. (1988). Halobacteroides acetoethylicus $\mathrm{sp}$. nov., a new obligately anaerobic halophile isolated from deep subsurface hypersaline environments. Syst Appl Microbiol 11, 28-35.

Sassar, M. (1990). Identification of bacteria by gas chromatography of cellular fatty acids. MIDI technical note 101. Newark, DE: MIDI.

Smibert, R. M. \& Krieg, N. R. (1994). Phenotypic characterization. In Methods for General and Molecular Bacteriology, pp. 655-682. Edited by P. Gerhardt, R. G. E. Murray, W. A. Wood \& N. R. Krieg. Washington, DC: American Society for Microbiology.

Tanner, R. S. (1997). Cultivation of bacteria and fungi. In Manual of Environmental Microbiology, pp. 52-60. Edited by C. J. Hurst, G. R. Knudsen, M. J. McInerney, L. D. Stetzenbach \& 
M. V. Walter. Washington, DC: American Society for Microbiology.

Tourova, T. P., Boulygina, E. S., Zhilina, T. N., Hanson, R. S. \& Zavarzin, G. A. (1995). Phylogenetic study of haloanaerobic bacteria by $16 \mathrm{~S}$ ribosomal RNA sequences analysis. Syst Appl Microbiol 18, 189-195.

Tsai, C.-R, Garcia, J.-L., Patel, B. K. C., Cayol, J.-L., Baresi, L. \& Mah, R. A. (1995). Haloanaerobium alcaliphilum sp. nov., an anaerobic moderate halophile from the sediments of Great Salt Lake, Utah. Int J Syst Bacteriol 45, 301-307.

Zeikus, J. G., Hegge, P. W., Thompson, T. E., Phelps, T. J. \& Langworthy, T. A. (1983). Isolation and description of Haloan- aerobium praevalens gen. nov. sp. nov., an obligately anaerobic halophile common to Great Salt Lake sediments. Curr Microbiol 9, 225-234.

Zhao, H., Yang, D., Woese, C. R. \& Bryant, M. P. (1989). Assignment of the syntrophic fatty acid-degrading anaerobe Clostridium bryantii to Syntrophospora bryantii gen. nov., comb. nov. Int J Syst Bacteriol 40, 40-44.

Zhilina, T. N., Zavarzin, G. A., Bulygina, E. S., Kevbrin, V. V., Osipov, G. A. \& Chumakov, K. M. (1992). Ecology, physiology and taxonomy studies on a new taxon of Haloanaerobiaceae, Haloincola saccharolytica gen. nov., sp. nov. Syst Appl Microbiol 15, 275-284. 